\title{
MARZENA CHROST \\ Kształtowanie kompetencji emocjonalnych w procesie formacji świeckich konsekrowanych
}

Proces formacji osób świeckich konsekrowanych jako całość jest bardzo złożony i może być rozpatrywany w wielu aspektach. Formacja powinna obejmować całego człowieka, czyli ma to być przede wszystkim głęboka formacja duchowa, dobra formacja psychologiczna, formacja do życia wspólnotowego i w samotności, do apostolstwa - a wszystko to powinno być zakotwiczone w charyzmacie danego Instytutu. W kontekście szeroko rozumianej problematyki dotyczącej wpisywania się formacji $\mathrm{w}$ proces rozwoju człowieka przedstawię zagadnienie kształtowania kompetencji emocjonalnych w procesie formacji świeckich konsekrowanych.

Sfera emocjonalna odgrywa podstawową rolę w życiu i działaniu każdego człowieka. Jest ona sferą najbardziej intymną, osobniczą, niewymierną, której nie można bezpośrednio czy też pośrednio zobiektywizować ${ }^{1}$. Podlega ona, tak jak i inne dziedziny funkcjonowania człowieka, ciągłemu rozwojowi. Dlatego też, obecnie w świecie, gdzie w zatrważającym tempie wzrasta brak poczucia sensu życia, a człowiek często staje się przedmiotem gry i manipulacji, niewątpliwie rodzi się potrzeba rozwijania kompetencji emocjonalnych. Zwrócenie uwagi na potrzebę kształtowania tych kompetencji w procesie formacyjnym jest ważne także w kontekście wyzwań, jakie stawia przed współczesnym człowiekiem cywilizacja informacyjna, tym bardziej, że obserwacja rzeczywistości wskazuje na pewien brak wiedzy i umiejętności, który określany jest analfabetyzmem emo-

Marzena C H R O ST, dr nauk humanistycznych w zakresie pedagogiki, adiunkt w Katedrze Kulturowych i Chrześcijańskich Podstaw Edukacji Instytutu Nauk o Wychowaniu, Wydział Pedagogiczny Wyższej Szkoły Filozoficzno-Pedagogicznej „Ignatianum” w Krakowie.

${ }^{1}$ Por. W. J a s i ń s k i: Aby wychowanie mogło stużyć rozwojowi. Katowice 1994 s. 89. 
cjonalnym $^{2}$. Bez właściwej edukacji analfabetą emocjonalnym może być każdy człowiek, dziecko i rodzic, uczeń i nauczyciel, pracodawca i pracownik, formator i formowany. Dlatego też każdy człowiek powinien rozwijać swoje emocjonalne kompetencje.

W związku z tym, w pierwszej kolejności omówię pojęcie kompetencji emocjonalnych, oraz przedstawię rozwojowe uwarunkowania ich kształtowania ze szczególnym zwróceniem uwagi na osiąganie dojrzałości emocjonalnej przez człowieka. Następnie ukażę formację jako pomoc w rozwijaniu kompetencji emocjonalnych w odniesieniu do trzech płaszczyzn działania: inspiracji, stymulacji i wsparcia.

\section{Kompetencje emocjonalne}

Pojęcie kompetencji emocjonalnych jest w literaturze różnie definiowane. Ludzkie kompetencje można traktować w trzech aspektach: psychologicznym, pedagogicznym, oraz socjologicznym ${ }^{3}$. W psychologicznym ujęciu są one wyrazem osobistych zdolności. Z punktu widzenia pedagogicznego są rezultatem edukacji, a socjologiczna ich charakterystyka wskazuje, że uzewnętrzniają się one w społecznych skutkach.

Do opisu rozwoju sfery emocjonalnej używane są między innymi pojęcia „kompetencji emocjonalnej” i ,inteligencji emocjonalnej”. Określenia te pojawiły się w latach dziewięćdziesiątych XX wieku i nie zostały jeszcze jasno i precyzyjnie zdefiniowane, nie ma również wyraźnego rozgraniczenia między tymi pojęciami i bardzo często używane są one zamiennie ${ }^{4}$.

Analizując literaturę dotyczącą pojęcia kompetencji emocjonalnych można zauważyć, że jest ono jeszcze w fazie dookreślania. Niektórzy autorzy nie posługują się ogólną definicją, lecz kompetencje emocjonalne określają, podając jej elementy składowe ${ }^{5}$. Porównując występujące w literaturze definicje pojęcia „kompetencji emocjonalnych”, można zauważyć wymiary wspólne, które koncentrują się między innymi na elementach: poznawczych, relacyjnych, rozwojowych, wychowawczych oraz umiejętności postępowania z emocjami.

\footnotetext{
${ }^{2}$ Por. U. L a m c z a k: Co to jest inteligencja emocjonalna?. „Edukacja i Dialog”. R. $2001 \mathrm{nr}$ $5(128)$ s. 45.

${ }^{3}$ Por. W. S r o c z y ń s k i: Pedagogika spoteczna a kompetencje spoteczne. „Pedagogika Społeczna”. R. $2002 \mathrm{nr} 4(6)$ s. 25.

${ }^{4}$ Por. A. Jasielska, M.A. L e o p o 1 d: Kompetencje a inteligencja emocjonalna - pojęcia tożsame czy różne?. „Forum Oświatowe”. R. 2000 nr 2(23) s. 26.

${ }^{5}$ Por. tamże, s. 11
} 
W wymiarze poznawczym kompetencje emocjonalne określone są jako rozumienie przekazów emocjonalnych zawartych $w$ kontekstach społecznych ${ }^{6}$, jako zdolność do rozumienia, nazywania, efektywnego postępowania $\mathrm{z}$ emocjami ${ }^{7}$, a także jako zdolność nabywania wiedzy i umiejętności posługiwania się emocjami zarówno własnymi, jak również innych osób ${ }^{8}$. Na element relacyjności zwraca się uwagę w definicjach, w których kompetencje emocjonalne przedstawiane są jako centralna zdolność istotna w interakcjach i relacjach z innymi ${ }^{9}$ oraz skuteczność, czyli zdolność i umiejętność, która ujawnia się $w$ relacjach społecznych wywołujących emocje ${ }^{10}$. Natomiast element rozwojowy akcentowany jest $\mathrm{w}$ definicji zaproponowanej między innymi przez Annę Jasielską i Mirosławę Leopold. Autorki stwierdzają, że kompetencja emocjonalna odnosi się do nabytych $w$ toku rozwoju umiejętności i sprawności emocjonalnych $^{11}$. Na aspekt wychowawczy zwracają uwagę Aleksandra Jaworowska i Anna Matczak. Uważają one kompetencje emocjonalne za konkretne umiejętności radzenia sobie $\mathrm{z}$ emocjonalnymi informacjami czy też problemami ${ }^{12}$. Podkreślają także, że nabywa się je dzięki posiadaniu bardziej ogólniejszych zdolności. Pojęcie to odnosi się zatem do wiedzy i umiejętności, które jednostka osiaga, by mogła funkcjonować $w$ sposób adekwatny w różnych sytuacjach $^{13}$.

Wszystkie przedstawione powyżej wymiary kompetencji emocjonalnych odnoszą się do umiejętności postępowania z emocjami, które wyrażają się przede wszystkim $\mathrm{w}$ relacjach $\mathrm{i}$ są potrzebne człowiekowi do funkcjonowania $\mathrm{w}$ zmieniającym się środowisku. Terminem pokrewnym, bliskoznacznym, czy też $\mathrm{w}$ niektórych wypadkach tożsamym $\mathrm{z}$ kompetencjami emocjonalnymi jest pojęcie ,inteligencji emocjonalnej”. Niemniej można stwierdzić, że kompetencje

${ }^{6}$ Tamże, s. 10.

${ }^{7}$ Por. R. B u c k: Social and emotional functions in facial expression and communication: the readout hypothesis, „Biological Psychology”. R. 1994 nr 38 s. 95-115, cyt. za A. J a s i e 1 s k a, M. A. L e o p old: Kompetencje a inteligencja emocjonalna - pojęcia tożsame czy różne?, art. cyt., s. 7.

${ }^{8}$ Por. W. A n d r u k o w i c z: Edukacja integralna. Kraków 2001 s. 106.

${ }^{9}$ Por. A. J a s i e $1 \mathrm{~s} \mathrm{k}$ a, M. A. L e o p o 1 d: Kompetencje a inteligencja emocjonalna-pojęcia tożsame czy różne?, art. cyt., s. 10; M. A. L e o p old: Rozumienie pojęcia kompetencja emocjonalna. „Polskie Forum Psychologiczne”. R. 2001 nr 2 s. 155-182; M. A. L e o p o 1 d : Kompetencja emocjonalna. „Remedium”. R. 2007 nr 7 s. 24-25.

${ }^{10}$ Por. C. S a a rn i: Kompetencja emocjonalna i samoregulacja $w$ dzieciństwie. W: Rozwój emocjonalny a inteligencja emocjonalna. Problemy edukacyjne. Pod red. P. S a lo v e y a, D. J. S l u y t e r a. Poznań 1999 s. 75-125.

${ }^{11}$ A. J a s i e $1 \mathrm{~s} \mathrm{k}$ a, M. A. Le o pold: Kompetencje a inteligencja emocjonalna - pojęcia tożsame czy różne?, art. cyt., s. 12.

${ }^{12}$ Por. A. J a w o r o w s k a, A. M a t c z a k: Kwestionariusz Inteligencji Emocjonalnej INTE. Podręcznik. Warszawa 2001 s. 11.

${ }^{13}$ A. J a s i e $1 \mathrm{~s} \mathrm{k}$ a, M. A. L e o p o $1 \mathrm{~d}$ : Kompetencje a inteligencja emocjonalna - pojęcia tożsame czy różne?, art. cyt., s. 27. 
emocjonalne odnoszą się do nabywanych w toku rozwoju umiejętności: spostrzegania i rozpoznawania emocji, ich rozumienia i nazywania oraz wyrażania i kierowania nimi, natomiast inteligencja emocjonalna zakłada istnienie pewnej wrodzonej zdolności, która stanowi podstawę dla rozwoju tych umiejętności emocjonalnych ${ }^{14}$.

Praktyczny wymiar kompetencji emocjonalnych podkreśla Carolyn Saarni, która uważa, że osoba posiadająca kompetencje emocjonalne ${ }^{15}$ :

- jest świadoma własnych stanów emocjonalnych oraz wie, że czasami można być nieświadomym swoich uczuć;

- umie równocześnie różnicować emocje przeżywane przez innych na podstawie sytuacyjnych wskaźników oraz ekspresji mimicznej;

- biegle używa słownictwa i wyrażeń opisujących stany emocjonalne, które obowiązują w danej kulturze;

- rozumie, że wewnętrzny stan emocjonalny może nie odpowiadać zewnętrznemu zachowaniu, zarówno u siebie samego jak i u innych oraz uwzględnia to w strategiach autoprezentacji;

- potrafi w sposób empatyczny angażować się w doświadczenia emocjonalne innych;

- umiejętnie radzi sobie z emocjami awersyjnymi czy przykrymi za pomocą odpowiednich strategii samoregulujących;

- cechuje ją skuteczność emocjonalna wyrażana przez akceptację swoich doświadczeń emocjonalnych;

- jest świadoma, że istota relacji międzyludzkich jest po części zdeterminowana jakością zachodzącej w niej komunikacji emocjonalnej ${ }^{16}$.

Przedstawione powyżej komponenty podlegają procesowi uczenia się, bowiem $w$ toku rozwoju osoba wyksztatca poszczególne sprawności, które ciagle może wzbogacać, będąc nawet na wyższym stadium rozwoju ${ }^{17}$.

Rozwijający się człowiek musi sprostać wyzwaniom i zadaniom, jakie pojawiają się w określonych fazach jego życia, dlatego też podejmowanie różnych zadań życiowych jest szansą dla rozwoju nowych kompetencji emocjonalnych i doskonalenia tych, które wcześniej już zostały wykształcone. W kompetencje wpisana jest zdolność do ciągłej reorganizacji jej struktury, co sprawia, że naby-

${ }^{14}$ Por. tamże, s. 12.

${ }^{15}$ Por. C. S a a r n i: The Development of Emotional Competence. New York 1999 s. 4; M. A. L e o p o ld: Kompetencja emocjonalna, art. cyt., s. 24-25.

${ }^{16}$ Por. C. S a a rn i: Kompetencja emocjonalna i samoregulacja $w$ dzieciństwie. W: Rozwój emocjonalny a inteligencja emocjonalna, dz. cyt., s. 94-117; A. J a s i e $1 \mathrm{~s} \mathrm{k}$ a, M. A. L e o p o $1 \mathrm{~d}$ : Kompetencje a inteligencja emocjonalna - pojęcia tożsame czy różne?, art. cyt., s. 10.

${ }^{17}$ A. J a s i e $1 \mathrm{~s} \mathrm{k}$ a, M. A. L e o p o ld: Kompetencje a inteligencja emocjonalna - pojęcia tożsame czy różne?, art. cyt., s. 9. 
wanie kompetencji nie jest nigdy procesem zamkniętym ${ }^{18}$. Należy zauważyć, że człowiek potrzebuje coraz wyższego poziomu kompetencji, aby optymalnie radzić sobie z wyzwaniami stawianymi mu przez życie. A chcąc również twórczo wpływać na okoliczności życia i kształtować je nie tylko na miarę swoich możliwości, ale tak, by móc przekraczać własne ograniczenia i podejmować nowe wyzwania, powinien posiadać coraz to wyższy poziom kompetencji emocjonalnych.

Podsumowując można stwierdzić, że kompetencje emocjonalne odnoszą się do wiedzy i umiejętności, które człowiek może osiągać w celu odpowiedniego funkcjonowania w różnorodnych sytuacjach. Na ich kształtowanie ma wpływ wrodzony charakter inteligencji emocjonalnej, środowisko zewnętrzne oraz własna aktywność człowieka. W wyniku tego jest się osobą kompetentną stosownie do wieku i etapu rozwoju, a efektem osiągnięcia wysokiego poziomu kompetencji jest skuteczność funkcjonowania w środowisku społecznym.

\section{Rozwojowe uwarunkowania kompetencji emocjonalnych}

Kształtowanie kompetencji emocjonalnych związane jest z rozwojem emocjonalnym człowieka. Zdaniem Ireny Obuchowskiej rozwój emocjonalny, czyli emocjonalne stawanie się, polega najogólniej na ukierunkowanych zmianach $w$ ustosunkowywaniu się do zjawisk zachodzacych wewnatrz, $w$ organizmie $i$ psychice dziecka oraz zachodzacych wokót niego ${ }^{19}$.

Rozwój emocjonalny powinien przebiegać w harmonii z rozwojem percepcyjnym, motorycznym i poznawczym ${ }^{20}$. Procesy poznawcze i emocje wzajemnie na siebie oddziałują, bowiem emocje wpływają na przebieg procesów poznawczych. Jednocześnie $w$ miarę rozwoju poznawczego następuje powiększanie się zakresów bodźców, które moga wywoływać reakcje emocjonalne, a zarazem różnicowanie się tych reakcji, prowadzace do jakościowego wzbogacenia sfery emocjonalnej. W wyraźnym związku z doskonaleniem się poznania pozostaja również zmiany dotyczace sposobu wyrażania emocji $i^{21}$.

W emocjach wyraża się stosunek osoby do samej siebie i do innych, do swoich celów życiowych, pracy, nauki. To właśnie emocje człowieka są reakcjami na jego własne zachowania i sytuacje życiowe, na osoby, sytuacje i wydarzenia

\footnotetext{
${ }^{18}$ Por. A. M ę c z k o w s k a: Kompetencja. W: Encyklopedia pedagogiczna XXI wieku. T. 2. Warszawa 2003 s. 696.

${ }^{19}$ I. O b u chowska: Wspomaganie rozwoju emocjonalnego: refleksje i propozycje. W: Wspomaganie rozwoju. Psychostymulacja $i$ psychokorekcja. Pod red. B. Kaji. Bydgoszcz 1997 s. 37.

${ }^{20}$ Por. H. R. S c h a f f e r: Rozwój społeczny dzieciństwo i młodość. Kraków 2006 s. 60.

${ }^{21}$ A. M atczak: Zarys psychologii rozwoju. Podręcznik dla nauczycieli. Warszawa 2003 s. 129.
} 
zewnętrzne, które wpływają na jego los. W zależności od okoliczności reakcje te mogą wyrażać się poprzez radość, wzruszenie, satysfakcję, poczucie bezpieczeństwa, zaufania, pewności siebie, albo poprzez niepokój, wstyd, poczucie winy, depresję, gniew, desperację, czy też nienawiść. Emocje pełnią główną rolę w regulacji zachowania zarówno na poziomie jednostkowym, jak i interpersonalnym. Stan emocjonalny na poziomie jednostkowym jest dominujacym komponentem naszej świadomości, który mówi nam coś o naszej własnej psychofizjologicznej reakcji na wydarzenia życia ${ }^{22}$. Natomiast na poziomie interpersonalnym polega on na widocznych znakach towarzyszacych emocjonalnym stanom innej osoby $i$ choć możemy odwotywać się tu do gestów i głosu, najbardziej wiarygodnej informacji dostarcza nam wyraz twarzy $y^{23}$. Emocje mają także wartość adaptacyjną. Spełniają one z jednej strony funkcje biologiczne, przez co umożliwiają regulację zachowania. Z drugiej zaś strony służą komunikowaniu, czyli spełniają funkcje społeczne ${ }^{24}$. Dlatego też emocje mogą być rozpatrywane jako język, sposób porozumiewania się. Rudolph H. Schaffer stwierdza, że okazywanie emocji jest jednym z pierwszych środków, poprzez które dziecko i jego opiekunowie porozumiewaja się z soba, dzięki specyficznym wrodzonym sposobom komunikowania odczuć emocjonalnych ${ }^{25}$. Osoby dojrzałe emocjonalnie wyrażaja swoje uczucia słowem, zachowaniem, mimika, gestem, milczeniem itp. - jest to nieodtaczne od normalnego dojrzałego życia ${ }^{26}$.

Jedną $\mathrm{z}$ charakterystycznych cech rozwoju emocjonalnego jest postępująca wraz $z$ wiekiem zmiana warunków wzbudzających poszczególne emocje ${ }^{27}$. Jest wiele czynników wywołujących emocje, jednak należy podkreślić, że wiele emocji powstaje $\mathrm{w}$ interakcjach $\mathrm{z}$ innymi ludźmi. Ogólnie można podzielić źródła reakcji emocjonalnych na pierwotne bądź wtórne bodźce emocjonalne. Pierwotne bodźce emocjonalne wywołują reakcje o charakterze bezwarunkowym. Należą do nich bodźce związane ze stanem zaspokojenia potrzeb fizjologicznych organizmu, wszystkie doznania zmysłowe pochodzenia zewnętrznego (wzrokowe, słuchowe, dotykowe). Natomiast znaczenia wtórnych bodźców emocjonalnych człowiek uczy się w toku rozwoju. Zdaniem Anny Matczak sq one poczatkowo neutralne $i$ dopiero $w$ wyniku powiazania $z$ pierwotnymi (bezwarunkowymi) bodźcami (lub bodźcami, które wcześniej nabraty charakteru warunkowych) nabywaja zdolności wywotywania emocji. Takie uczenie się emocji, zaczyna się już w pierwszych tygodniach po urodzeniu i trwa aż do końca życia. Następuje za

${ }^{22}$ H. R. S c h a f f e r: Rozwój spoteczny dzieciństwo i młodość, dz. cyt., s. 57.

${ }^{23}$ Tamże, s. 57.

${ }^{24}$ Por. tamże, s. 60.

${ }^{25}$ Tamże, s. 61.

${ }^{26}$ A. A. T e r r u w e, C. W. B a a r s: Integracja emocjonalna. Jak uwierzyć, że jesteś kochany i potrafisz kochać. Poznań 2004 s. 24.

${ }^{27} \mathrm{H}$. H u r m e: Rozwój emocjonalny. W: Psychologia rozwoju człowieka. Rozwój funkcji psychicznych. T. 3. Pod red. B. H a r w a s - N a p i e r a ł y, J. Tr e m p a ł y. Warszawa 2006 s. 47. 
pośrednictwem procesów warunkowania i generalizacji ${ }^{28}$. Należy jednak zauważyć, że obecnie emocje nie sa już rozpatrywane jako proste konsekwencje sytuacji bodźcowych czy też reakcji na nie ${ }^{29}$. Natomiast coraz częściej rozpatrywane są one $w$ relacjach ze środowiskiem materialnym i społecznym. Podstawą dla kształtowanie kompetencji emocjonalnych jest osiąganie dojrzałości emocjonalnej przez człowieka.

\section{Osiąganie dojrzałości emocjonalnej}

Emocjonalność człowieka jest wykorzystywana w procesie rozwoju, który ma prowadzić do dojrzałej osobowości i samorealizacji. Jak stwierdza Wiesław Skrzyński, proces dojrzewania emocjonalnego nie jest łatwy, a jego osiagnięcie nie jest wcale udziatem wszystkich wraz $z$ osiagnięciem takiego czy innego wieku ${ }^{30}$, czyli sam poziom wieku nie jest jeszcze gwarantem dojrzałości człowieka, jako że dojrzałość emocjonalną uzyskuje się w różnym czasie i w różnym zakresie. Zatem kryteria dojrzałości uczuciowej są niejednolite i trudne do sprecyzowania.

W procesie kształtowania kompetencji emocjonalnych ważne jest harmonijne realizowanie poszczególnych kryteriów rozwojowych. To zaś wiąże się z trudem nieustannego dorastania emocjonalnego. Dojrzałość emocjonalną w koncepcji Gordona Allporta ${ }^{31}$ charakteryzuje wiele zachowań, między innymi brak nadmiernej reakcji na bodźce wypływające $\mathrm{z}$ popędów, umiejętność rozwiązywania trudności, akceptowanie popędu seksualnego, umiejętność opanowania lub zaspokajania go w sposób społecznie akceptowany. Wyraża się ona także brakiem nadmiernej reakcji na sytuacje lękorodne, poprzez właściwe zachowanie się $\mathrm{w}$ sytuacjach zagrożenia. Inną właściwością dojrzałości emocjonalnej jest znalezienie jakiegoś wyjścia z trudnej sytuacji albo pogodzenie się z nią. Kolejne cechy takiej dojrzałości wyraża również akceptowanie swoich słabości i porażek bez poczucia klęski, umiejętność życia w zgodzie ze swoimi stanami emocjonalnymi, poczucie bezpieczeństwa psychicznego, zachowanie proporcji pomiędzy poczuciem zagrożenia i niepokojem oraz liczenie się $\mathrm{z}$ przekonaniami i uczuciami innych ludzi.

\footnotetext{
${ }^{28}$ A. M a t c z a k: Zarys psychologii rozwoju, dz. cyt., s. 130.

${ }^{29}$ H. Hurme: Rozwój emocjonalny, art. cyt., s. 66.

${ }^{30}$ W. S k r z y ń s k i: Rozwój spoteczno-emocjonalny. W: Wprowadzenie do psychologii rozwoju człowieka. Pod red. J. S t y p u 1 o w s k i e j, Warszawa 2001 s. 92.

${ }^{31}$ Koncepcję Gordona A 11 porta przytaczam za: Z. Płu że k: Psychologia pastoralna. Kraków 1991 s. 54-55.
} 
Inną koncepcję dojrzałej osobowości na poziomie emocjonalnym przedstawia William Menninger ${ }^{32}$. Wyróżnia on następujące kryteria dojrzałej osobowości, którą określa jako dojrzałość emocjonalną. Jako pierwsze kryterium podaje zdolność do funkcjonowania w sytuacjach trudnych. Uważa, że im lepiej człowiek potrafi funkcjonować pomimo trudności, przeciwności, tym jest bardziej dojrzały. Drugie kryterium - to zdolność do zmiany własnej osobowości, bo jak twierdzi, plastyczność jest lepsza od sztywności postaw. Polega ona na tym, by w każdej sytuacji umieć dostrzec swoją odpowiedzialność, a to wymaga umiejętności przewidywania. Kolejnym kryterium jest zdolność radzenia sobie $\mathrm{z}$ napięciami, lękami i niepokojami. Autor ten podkreśla, że człowiek dojrzały emocjonalnie nie jest wolny od różnych negatywnych emocji, ale umie sobie z nimi radzić. Za następne kryterium uznaje większą zdolność do dawania niż do brania. Bowiem zachęca to do podejmowania zadań bardzo trudnych, pozornie przerastających człowieka, przysparzających rozwój wspólnego dobra. Życie w zgodzie z innymi to kolejne wyróżnione przez autora kryterium. Wyraża się ono w tym, że człowiek emocjonalnie dojrzały umie dostrzec w sobie negatywne postawy, takie jak wnoszenie niepokoju w układy personalne, przeszkadzanie innym $\mathrm{z}$ pozycji niechęci i uprzedzeń międzyludzkich. Istotnym kryterium jest również relacja, jaka istnieje między nienawiścią a poczuciem winy. Często nienawiść skierowana jest do wszystkich ludzi, do jakiejś grupy, do idei, do ludzi jakiejś klasy, wreszcie do siebie samego, a to prowadzi do poczucia winy. Potrzeba miłości jest ostatnim kryterium określającym dojrzałą osobowość. Miłości drugiej osoby trzeba się uczyć, a umiejętność życia zgodnie z potrzebą miłości odbieraną od innych i dawaną innym łączy się z dojrzałością społeczną.

Dojrzałość emocjonalna powinna być zakorzeniona $w$ petni rozwiniętym życiu emocjonalnym, obejmującym wszystkie uczucia bez wyjątku, całkowicie zintegrowanym, przenikniętym przez kompetentny intelekt $i$ życzliwa wolna wolę $e^{33}$. Wymaga ona również zdolności znoszenia napięcia, jakie wyzwala się $w$ stanie pozbawienia, zagrożenia lub odmowy zaspokojenia $w$ zakresie różnych potrzeb, bez ujawniania agresji lub burzliwych reakcji emocjonalnych ${ }^{34}$. Polega ona przede wszystkim na umiejętności opanowania emocji, ich zrównoważeniu, umiejętności przeżywania sytuacji trudnych oraz coraz wyższym poziomie uczuć wyższych ${ }^{35}$. Można zatem stwierdzić, że dojrzałość emocjonalna przejawia się więc przede wszystkim $\mathrm{w}$ adekwatności reakcji uczuciowych $\mathrm{w}$ stosunku do obiektywnej sytuacji, w stopniu uświadomienia sobie treści własnych uczuć i ich

\footnotetext{
${ }^{32}$ Koncepcję W illia ma Menn inger a przytaczam za: Z. Płuże k: Psychologia pastoralna, dz. cyt., s. 40-44.

${ }^{33}$ A. A. T e r r u w e, C. W. B a a r s: Integracja psychiczna. Poznań 1987 s. 273.

${ }^{34}$ E. S u j a k: Życie jako zadanie. Warszawa 1978 s. 155.

${ }^{35}$ W. S k r z y ń s k i: Rozwój społeczno-emocjonalny, art. cyt., s. 84.
} 
roli $\mathrm{w}$ motywowaniu określonych działań. Zdaniem Marii Błażejczyk za podstawowy przejaw dojrzałości emocjonalnej przyjmuje się zachowanie człowieka wyposażonego $w$ optymalne parametry wtaściwego czasu, właściwej formy $i$ właściwego natężenia ${ }^{36}$. Dojrzałość taka - według Elżbiety Sujak manifestuje się między innymi niestawianiem wtasnych codziennych potrzeb na pierwszym miejscu i bez względu na potrzeby innych, ale zwtaszcza zdolnościa do objęcia opieka, to znaczy działaniem na rzecz zaspokajania potrzeb innych, powierzonych lub powierzajacych się ludzi $i^{37}$. Dlatego też - jak zauważa Elżbieta Wójcik - uporzadkowana, dojrzała uczuciowość jest wielkim bogactwem osoby. Jeżeli jest ona niedojrzała, chaotyczna, nie zwiazana z rozumem, wówczas to, co się podoba, co budzi sympatię, wydaje się $w$ danej chwili bezwzględnie najważniejsze $e^{38}$.

Charakteryzując człowieka dążącego do osiągania dojrzałości emocjonalnej, można go określić jako kogoś, kto zdaje sobie sprawę z przeżywanych stanów emocjonalnych, nie poddaje się dramatycznym i bolesnym stanom i nie kieruje się nimi. Trudne emocje traktuje jako punkt wyjścia do refleksji nad własnym zachowaniem i życiem, natomiast w swoim postępowaniu kieruje się między innymi świadomością, miłością, odpowiedzialnością i wolnością. Jednocześnie dobrze zdaje sobie sprawę $\mathrm{z}$ tego, że przeżywane przez niego emocje mogą sygnalizować nieuświadomione problemy. Ponieważ emocje informują człowieka o jego sytuacji życiowej, która nieustannie się zmienia, dlatego też dojrzałość emocjonalna nie oznacza, że przeżywane są tylko miłe nastroje, a brak jest doznań trudnych i bolesnych, takich jak: niepokój, lęk, gniew czy rozgoryczenie. Można stwierdzić, że osoba dojrzała emocjonalnie jest zdolna do spisywania własnych stanów emocjonalnych i nazywania rzeczy po imieniu ${ }^{39}$.

Ważnym warunkiem charakteryzującym dojrzałą postawę w sferze emocjonalnej jest również prawidłowe rozumienie relacji pomiędzy moralnością a emocjami. Trzeba bowiem podkreślić, że uczucia i emocje są moralnie neutralne, ponieważ są spontaniczną reakcją organizmu na określone osoby, sytuacje czy też wydarzenia ${ }^{40}$. Natomiast ocenie moralnej podlega postawa człowieka wobec tego, co dzieje się $w$ jego sferze emocjonalnej, a także zachowania związane z przeżywanymi emocjami.

${ }^{36}$ M. B ł a ż e j c z y k: Wychowanie do dojrzatości emocjonalnej. „Edukacja i Dialog”. R. $2005 \mathrm{nr} 4(167) \mathrm{s} .17$.

${ }^{37}$ E. S u j a k: Życie jako zadanie, dz. cyt., s. 155.

${ }^{38}$ E. W ó j c i k: Kobieta myśli sercem - czy to prawda i co to znaczy?. W: Świat ludzkich uczuć. Pod red. W. S z e w c z y k a. Tarnów 1997 s. 216.

${ }^{39}$ S. M o r g a 11 a: Duchowość daru z siebie. Kraków 2010 s. 139-140.

${ }^{40}$ Por. M. D z i e w i e c ki: Osoba i wychowanie. Pedagogika personalistyczna $w$ praktyce. Kraków 2003 s. 88. 
Elementem dojrzałości emocjonalnej jest także zdolność do uznawania odpowiedzialności za własne stany emocjonalne, która wyraża się w tym, że nie powinno obarczać się drugiego człowieka odpowiedzialnością za doznawane przeżycia. Ma to bardzo pozytywną konsekwencję, ponieważ oznacza, że człowiek posiada władzę modyfikowania swoich reakcji emocjonalnych. Może stać się kimś bardziej zrównoważonym i emocjonalnie zdystansowanym w obliczu danych osób, wydarzeń czy też sytuacji. Należy podkreślić, że przeżycia człowieka nie są nigdy czymś przypadkowym, a jego sfera psychiczna nie jest odizolowana od pozostałych jego wymiarów, dlatego też ważna jest świadomość, że nie można na trwałe poprawić przeżywanych uczuć i nastrojów bez pozytywnej modyfikacji własnego postępowania.

Człowiek dojrzały emocjonalnie kształtuje również w sobie prawidłową relację między uczuciami a motywacją. Powinien zatem czynić to, co w danym momencie jest wartościowsze, a nie emocjonalnie przyjemniejsze, a podstawowym motywem jego działania winna być odpowiedzialność, prawda, miłość a nie potrzeby i stany uczuciowe. Dlatego też, jak podkreśla Maria Błażejczyk przejawem emocjonalnej dojrzałości jest więc skuteczność $w$ funkcjonowaniu jednostki zarówno w sferze psychologicznej, jak i społecznej ${ }^{41}$. Wynika $\mathrm{z}$ tego, że fenomen osiągania emocjonalnej dojrzałości polega na świadomości celu własnego życia, stabilności zasadniczych dyspozycji, umiejętności selekcji niekorzystnych zmiennych, jak też ekspozycji pożądanych wzorców emocjonalnego reagowania. Zatem dojrzałość emocjonalną można określić jako sprawdzony mechanizm regulacji życia społecznego, stały punkt odniesienia $w$ procesie osobistego wzrastania $i$ kształtowania ludzkiej tożsamości ${ }^{42}$. Dążenie do osiągania dojrzałości w sferze emocjonalnej jest bardzo ważnym zadaniem $w$ procesie formacji.

\section{Formacja jako pomoc w rozwijaniu kompetencji emocjonalnych}

Formacja jest ważnym elementem życia duchowego. W życiu człowieka nie chodzi o dążenie do doskonałości, ale do świętości. A powołanie do świętości, które jest wspólne wszystkim chrześcijanom, wymaga ciągłego rozwoju i doskonalenia. Człowiek, w swojej wolności, wezwany jest przez Boga, by róst, dojrzewat i przynosił owoc ${ }^{43}$. Wydaje się, że wezwanie to powinno w sposób szczególny odnosić się do osób świeckich konsekrowanych.

Należy zauważyć, że formacja jest doniostym procesem, dzięki któremu człowiek nawraca się $w$ głębi swego istnienia ku Słowu Bożemu, a jednocześnie

${ }^{41}$ M. B ła ż ej cz y k: Wychowanie do dojrzałości emocjonalnej. „Edukacja i Dialog”. R. $2005 \mathrm{nr} 4(167)$ s. 18.

${ }^{42}$ Por. tamże.

${ }^{43}$ J a n P a w e ł I I: Adhortacja apostolska Christifideles laici. Watykan 1988 nr 57. 
uczy się sztuki szukania Bożych znaków w rzeczywistości tego świata ${ }^{44}$. Stwierdzenie to jest ważne szczególnie w odniesieniu do osób świeckich konsekrowanych, które starają się łączyć konsekrację ze świeckością oraz kontemplację z działaniem. Realizacja tego zadania wymaga najpierw dobrego przygotowania poprzez formację, która powinna być systematyczna, dostosowana do osoby, postęujaca i integralna ${ }^{45}$.

Warto podkreślić, że formacja w warunkach codzienności stawia duże wymagania, ponieważ trzeba pogodzić dotychczasowe zaangażowania z nowymi, należy znaleźć czas na modlitwę i na to wszystko, co służy formacji ogólnoludzkiej, duchowej i teologicznej. Trzeba umieć wybierać i również rezygnować z tego, co w hierarchii wartości jest mniej ważne. Oczywiście, jest program formacyjny i pomoc ze strony osoby pełniącej funkcję odpowiedzialnej za formację, niemniej nawet najbardziej kompetentna pomoc, niestety nie zastąpi własnej inicjatywy i wysiłku jaki jest konieczny w okresie formacji. Ważne jest zatem, żeby osoba nie tylko świadomie poddawała się procesowi formacji, ale także aby angażowała się w nią, bo każdy sam jest odpowiedzialny za swoją formację.

Zwykle na początku jakiejś drogi jest formacja początkowa. Ale na niej nie może się ona zakończyć, bowiem powinno to rozpoczynać formację ciągłą. To zmaganie formacyjne podejmowane jest do końca życia, bez przerwy aż do śmierci. Można stwierdzić, że formacja ciągła - to podjęcie decyzji, że chcę kształtować w sobie uczucia Syna, bowiem jeśli patrze na Chrystusa, wtedy moje serce będzie upodabniato się do jego serca ${ }^{46}$. Formacja ustawiczna jest wewnętrznym wymogiem w rzeczywistości świeckiej konsekracji. Jest ona ciągłym naśladowaniem Chrystusa w świecie, a to nie dokonuje się raz na zawsze, ale ciągle chwila po chwili.

Zasadniczym celem formacji w Instytucie Świeckim jest aby prawdziwie pomóc osobie, by mogła odpowiedzieć na swoje powołanie i wypetnić swoja misję $w$ świecie zgodnie z planem Bożym, formacja $w$ instytucie świeckim powinna sprzyjać rozwojowi całościowemu i jednolitemu tej osoby, wedtug jej zdolności $i$ warunków $^{47}$. By realizować te cele, osoba powinna cechować się wielka dojrzatościa, zarówno ludzka jak i chrześcijańska, emocjonalna równowaga, (...) oraz zdolnościa przyjęcia zobowiąań płynących z przynależności do instytutu ${ }^{48} . \mathrm{W}$ związku z tym w procesie formacji ważne jest zwracanie uwagi na rozwój emo-

${ }^{44}$ J a n P a w e ł I I: Adhortacja apostolska Vita consecrata. Watykan $1996 \mathrm{nr} 68$.

${ }^{45}$ P. W a 1 k i e w i c z: Duchowość świeckich konsekrowanych. Lublin 2003 s. 109.

${ }^{46}$ J. M a u r e d e r: Wybierz wtasna drogę. Kraków 2008 s. 20.

${ }^{47}$ Kongregacja ds. Zakonów i Instytutów Świeckich: Formacja w instytutach świeckich. W: Z Chrystusem $w$ świecie. Instytuty świeckie w 50-lecie Provida Mater Ecclesia. Pod red. M. Ch mi e le w s ki e g o, W. S ł o m ki, K. S t a w e c k i e j. Lublin 1997 s. 107.

${ }^{48}$ P. W a 1 k i e w i c z: Duchowość świeckich konsekrowanych, dz. cyt., s. 111. 
cjonalny osoby, który wyraża się między innymi w kształtowaniu kompetencji emocjonalnych.

Kompetencje emocjonalne są silniej związane z procesami edukacyjnymi niż ze zdolnościami psychicznymi ${ }^{49}$. Wynika stąd praktyczny wniosek, że celem oddziaływań edukacyjnych, formacyjnych powinno być nie tylko rozwijanie poszczególnych kompetencji emocjonalnych, ale także uczenie stosowania ich w realnych warunkach. Można zatem stwierdzić, że kompetencje emocjonalne wymagają przepracowania, rekonstrukcji czy też reedukacji w procesie uczenia się, $\mathrm{w}$ procesie formacji.

Podstawą procesu formacji jest własne działanie osoby formowanej, dlatego też praca nad rozwijaniem kompetencji emocjonalnych zależy przede wszystkim od przekonania danej osoby, że doskonalenie tych umiejętności jest ważne i korzystne. Emocje podlegają prawom uczenia się, a poprzez odpowiednie oddziaływania wychowawcze, formacyjne można je w zamierzony sposób kształtować, dlatego warto być szczerym wobec samego siebie, po to aby wychowywać uczu$\mathrm{cia}^{50}$. Należy zauważyć, że praca nad uczuciami polega na rozpoznawaniu $i$ kontrolowaniu budzacych się $w$ nas odruchowo 'nieuporzadkowanych uczuć' $i$ próbie życzliwego rozumienia, $w$ swoich nieuporzadkowanych uczuciach, siebie $i$ bliźniego ${ }^{51}$.

Kształtowanie kompetencji emocjonalnych w procesie formacji może przebiegać w bardzo zróżnicowany sposób, dlatego też omówię to zagadnienie w odniesieniu do trzech płaszczyzn oddziaływań formacyjnych: inspiracji, stymulacji oraz wspierania.

\section{Inspirowanie kształtowania kompetencji emocjonalnych}

Proces kształtowania kompetencji emocjonalnych dokonuje się w pewnej sytuacji wychowawczej, to jest w sytuacji, w której oddziałują na siebie nawzajem formator i formowany. Formator w tym procesie odgrywa ważną rolę, ponieważ na jego barkach spoczywa obowiązek kierowania tym procesem i odpowiedzialność za jego powodzenie. Nie można samemu rozeznać się $w$ świecie swoich uczuć. Aby móc je obiektywnie ocenić, dostrzec ich źródta oraz wpływ na nasze wybory i decyzje, potrzebujemy pomocy człowieka doświadczonego ${ }^{52}$. Podstawo-

\footnotetext{
${ }^{49}$ Por. J. D. M a y e r, P. S a 1 o v e y: Czym jest inteligencja emocjonalna? W: Rozwój emocjonalny a inteligencja emocjonalna. Problemy edukacyjne. Pod red. P. S a 1 o v e y a, D. J. S 1 u y t e r a. Poznań 1999 s. 43-44.

${ }^{50}$ A. C e n c in i: Synowskie uczucia. Droga formacyjna $w$ życiu konsekrowanym. Kraków 2005 s. 187.

${ }^{51}$ J. A u gu sty n: Świat naszych uczuć. Mały przewodnik w poznawaniu i kształtowaniu ludzkich uczuć. Kraków 2001 s. 18.

${ }^{52}$ Tamże, s. 39.
} 
wym narzędziem formacji jest formator, dlatego też dobry formator powinien pełnić rolę inspiratora kształtowania kompetencji emocjonalnych.

Inspirować do kształtowania kompetencji emocjonalnych może tylko ktoś, kto sam takie kompetencje posiada. Osiąganie przez osobę formowaną dojrzałego poczucia emocjonalnych kompetencji w dużej mierze zależy od postawy, jaką reprezentuje formator bowiem wymagając posługiwania się określonymi kompetencjami, musi najpierw sam je posiadać i stosować.

Aby formator mógł pełnić rolę inspiratora, musi wykazywać się następującymi podstawowymi umiejętnościami: nawiązywania i podtrzymywania relacji, tworzenia atmosfery podmiotowości i współpracy, aby powstały warunki do stymulowania i wspomagania rozwoju. Bez tych umiejętności, które stanowią w rzeczywistości warunek wstępny dla procesu rozwojowego, trudno wyobrazić sobie bycie dobrym formatorem.

Podstawą interakcji formacyjnych jest komunikowanie się. Umożliwia ono tworzenie sytuacji edukacyjnych, współdziałanie i rozwiązywanie problemów w układzie wielopodmiotowym. W związku z tym, aby formacja była procesem porozumiewania się, konieczna jest zmiana interakcji opartych na wzajemnym spostrzeganiu na interakcje oparte na wzajemnym porozumiewaniu się ${ }^{53}$. Bowiem tylko bezpośrednie spotkanie formatora i formowanego oraz postawa dialogu mogą sprawić, że formator zamiast być „mistrzem nauczania”, stanie się „mistrzem życia”.

\section{Stymulowanie kształtowania kompetencji emocjonalnych}

Stymulowanie polega na dostarczaniu bodźców, które spowodują decyzje rozwojowe i chęć podejmowania wysiłku zmiany. Ma ono charakter bardziej aktywny niż inspirowanie, które oparte jest bardziej na budowaniu własnej spójnej postawy formatora, która miałaby siłę inspirującą. W stymulacji formator powinien podejmować konkretne działania, które mają pobudzać do rozwoju. Trzeba zauważyć, że rozwój kompetencji emocjonalnych zależy od tego, jak są rozpoznawane i zaspokajane potrzeby emocjonalne człowieka, dlatego głównym działaniem stymulującym będzie bezpośrednie i pośrednie zaspokajanie potrzeb $^{54}$. Bezpośredni sposób będzie polegał na likwidowaniu poczucia zagrożenia i stwarzaniu poczucia bezpieczeństwa. Natomiast pośrednie zaspokajanie potrzeb będzie uwzględniało regulowanie dopływu stymulacji do poziomu optymalnego, czyli zaspokajanie potrzeb poznawczych. Dzieje się to przez dostarczanie optymalnej ilości informacji oraz organizowanie odpowiednich warunków i sytuacji,

\footnotetext{
${ }^{53}$ Por. W. A n d r u k o w i c z: Teoria ksztatcenia integralnego. Gorzów Wlkp. 2000 s. 134.

${ }^{54}$ Por. A. M a tc z a k: Rozwój osobowości. W: Wprowadzenie do psychologii. Pod red. Z. W ł od ars ki e g o, A. M a t c z a k. Warszawa 1996 s. 140.
} 
które sprzyjają ich zaspokajaniu, a także przez proponowanie sposobów ich zaspokajania.

Stymulacja może dokonywać się także poprzez kształtowanie równowagi emocjonalnej, czyli uczenie właściwego reagowania emocjonalnego w sposób proporcjonalny do danej sytuacji, bodźca, wydarzenia czy też rodzaju spotkania z drugą osobą. Brak tej właściwej proporcji może wyrażać się między innymi w postaci nadwrażliwości emocjonalnej, jak również w postaci obojętności emocjonalnej. Dzięki stymulowaniu właściwych zachowań możliwe będzie osiąganie $\mathrm{w}$ tej dziedzinie dojrzałości, która przejawia się w umiejętności przeżywania stanów emocjonalnych przez formowanego, proporcjonalnie do danej sytuacji, zachowań czy formy kontaktów międzyosobowych.

W tym kontekście w procesie formacji powinno się zmierzać do wzrostu świadomości u osoby formowanej tego, co przeżywa oraz umiejętności dystansowania się od własnych przeżyć i powiązań emocjonalnych. Można zatem stwierdzić, że jest to promowanie równowagi między emocjonalną więzią formowanego z samym sobą, a jego więzią z innymi, między emocjonalną troską o siebie, a troską o innych.

Stymulować rozwój kompetencji emocjonalnych to także pomagać w uświadomieniu i zrozumieniu problemów czy też aktualnie przeżywanych konfliktów. Bowiem rozmowy, dyskusje $i$ analizowanie pewnych stanów uczuciowych i postaw, takich jak szacunek, wdzięczność, wspótczucie, przebaczenie, przyjaźń, miłość i odpowiedzialność, moga uczyć właściwego rozumienia ich treści i praktycznego ich realizowania w konkretnych sytuacjach życiowych ${ }^{55}$.

Przyjmując, że kompetencje emocjonalne są umiejętnościami do przeżywania bogatego zróżnicowania świata uczuć, panowania nad swoimi emocjami, ich kontrolowania i wyrażania, należy stwierdzić, że w aspekcie formacyjnym bardzo potrzebna jest mediacja świadomości, woli i wartości w zajęciu dojrzałej postawy wobec przeżywanych przez osobę uczuć. Bardzo ważne jest poznawanie własnych uczuć, gdyż one często pozwalaja nam zrozumieć, co kryje się w głębi naszego $\operatorname{serca}^{56}$. Dobrze ukształtowana sfera emocjonalna osoby formowanej będzie wpływała pozytywnie i ułatwiała osiąganie przez nią dojrzałości emocjonalnej. Natomiast należy zauważyć, że osoba unikająca kontaktu z tym, co dzieje się w jej sferze emocjonalnej, traci szansę na zrozumienie własnej sytuacji życiowej oraz ryzykuje, że nieuświadomione emocje zaczną kierować jej myśleniem, postępowaniem, a w konsekwencji także całym jej życiem.

${ }^{55} \mathrm{G} . \mathrm{M}$ a $1 \mathrm{c}$ h e r: Znaczenie rodziny $w$ rozwoju uczuć dzieci i młodzieży. W: Wychowanie w rodzinie. Pod red. F. A d a m s k i e g o. Kraków 1991 s. 89.

${ }^{56}$ A. C e n c i n i: Od wychowania do formacji. Kraków 2005 s. 29. 
W kontekście powyższych stwierdzeń rolą stymulacji będzie pomoc w nabywaniu umiejętności rozumienia uczuć. Proces ten jest związany z wrażliwością na uczucia własne i innych, której można się nauczyć. A najlepszym sposobem jest uczenie się przez doświadczenie. Ten proces uczenia się przynosi najlepsze wyniki wtedy, kiedy przebiega w odpowiednich i bezpiecznych warunkach, gdy ludzie mogą ćwiczyć się w mówieniu wprost bez obawy, że inni wykorzystają ich słabe strony.

Stymulowanie procesu kształtowania emocjonalnych kompetencji poprzez nabywanie umiejętności zrozumienia sensu ludzkiej sfery emocjonalnej winno odbywać się ze szczególnym zwróceniem uwagi na to, że przeżywanie emocji nie jest przejawem niedojrzałości czy też słabości człowieka, lecz cennym źródłem informacji na temat jego własnej sytuacji życiowej. Osoba znająca i wyrażająca własne uczucia może aktywniej kształtować kontakty z innymi i rozsądnie podejmować decyzje. Dzięki temu nie jest ona zależna od emocji, ale wykorzystuje je jako siłę twórczą ${ }^{57}$. Udoskonalanie kompetencji emocjonalnych opartych między innymi na lepszym poznaniu siebie jest warunkiem zadowolenia z życia społecznego.

Stymulowanie kształtowania kompetencji emocjonalnych polega również na rozpoznawaniu błędnych sposobów komunikowania się z innymi ludźmi. Można zaobserwować, że najbardziej bolesnymi i nieprawidłowymi sposobami są między innymi: posługiwanie się drugim człowiekiem jak rzeczą, manipulacja, szantażowanie, zadawanie fizycznego, psychicznego czy moralnego bólu, rażąca niesprawiedliwość, agresja oraz przemoc ${ }^{58}$. Stymulacja jest tylko pewnym sposobem pomocy bowiem ostatecznie o rozwoju człowieka decyduje przyjęcie na siebie odpowiedzialności za własny rozwój.

\section{Wspieranie kształtowania kompetencji emocjonalnych}

O wsparciu można mówić wtedy, gdy osoba zainspirowana i odpowiednio stymulowana weszła już na drogę rozwoju, nabyła pewne kompetencje emocjonalne i pragnie ten proces kontynuować. Potrzebuje wówczas wsparcia. Kształtowanie kompetencji emocjonalnych związane jest przede wszystkim z procesem zmiany, który polega między innymi na doskonaleniu umiejętności emocjonalnych, strategii działania i nawyków, dzięki którym człowiek może funkcjonować skuteczniej, bardziej adekwatnie do sytuacji oraz z większą satysfakcją ${ }^{59}$. Zmiany te obejmują stronę poznawczo-instrumentalną, która wiąże się z poznaniem rze-

\footnotetext{
${ }^{57}$ Por. C. W e i s b a ch, U. D a c h s: Inteligencja emocjonalna. Uczucia. Intuicja. Sukces. Warszawa 2000 s. 15.

${ }^{58}$ Por. M. D z i e w i e c k i: Osoba $i$ wychowanie, dz. cyt., s. 117.

${ }^{59}$ Por. P. S m ół k a: Kompetencje spoteczne. Metody pomiaru i doskonalenia umiejętności interpersonalnych. Kraków 2008 s. 122.
} 
czywistości i posługiwaniem się wiedzą w jej przetwarzaniu, a także stronę aksjologiczną, która polega na kształtowaniu stosunku człowieka do innych ludzi, do świata, systemu wartości i celu życia, życiowych postaw i przekonań światopoglądowych.

Ważnym działaniem jest kształtowanie poczucia kompetencji oraz pomaganie w procesie zmiany, dlatego też dobrze rozwinięte poczucie kompetencji powinno być oparte na realistycznym postrzeganiu samego siebie, a równocześnie nie powinno pozbawiać człowieka nadziei na przyszłość

Należy podkreślić, że kształtowanie kompetencji emocjonalnych wiąże się z poczuciem własnej tożsamości, dlatego też rozwijanie ich w procesie formacyjnym wymaga nie tylko zmiany na poziomie behawioralnym, ale także na poziomie postrzegania samego siebie. Fakt ten ma kluczowe znaczenie i związany jest z przeprowadzeniem zmian w obszarach dotyczących strategii samorealizujących i zachowań społecznych oraz postrzegania samego siebie ${ }^{60}$. Pierwszy rodzaj zmiany może być wprowadzony w stosunkowo krótkim czasie, natomiast zmiana w zakresie postrzegania samego siebie wymaga długoterminowego wsparcia.

Podsumowując można stwierdzić, że kompetencje emocjonalne człowiek może rozwijać każdego dnia, spotykając nowych ludzi oraz uczestnicząc w codziennych wydarzeniach. Nabywane są one wraz z wiekiem, jednak sama wiedza teoretyczna dotycząca kompetencji jest niewystarczająca bez jej praktycznego zastosowania w sytuacjach doświadczeń społecznych, rodzinnych, rówieśniczych i wspólnotowych.

Ważne jest zatem nieustanne uczenie się nowych umiejętności poprzez podejmowanie, rozwijanie i utrzymywanie zadawalających i różnorodnych relacji międzyludzkich. Aby kształtowanie kompetencji emocjonalnych było efektywne, trzeba je po prostu rozwijać już od najmłodszych lat oraz skutecznie usprawniać w okresie adolescencji i dorosłości. Rozwijanie samokontroli, zapału, wytrwatości, zdolności, motywacji czy empatii staje się edukacyjna koniecznościa. Jest wiele sytuacji, gdzie emocje liczq się często bardziej niż intelekt. Emocje kieruja nami wtedy, kiedy stajemy przed zadaniami zbyt ważnymi, aby zmierzenie ich pozostawić samemu rozumowi. Uczucia sa ważne dla myśli, a myśli dla uczućc1. Oprócz ważnego wymiaru intelektualnego istnieje więc jeszcze coś, co powinno z nim współgrać, a są to emocje, które pełnią ważną, doniosłą i znaczącą rolę w życiu każdego człowieka. Emocje i wiedza na ich temat oraz kompetencje emo-

\footnotetext{
${ }^{60}$ Por. M. A r g y l e: Nowe ustalenia $w$ treningu umiejętności spotecznych. W: Reguty życia spotecznego. Oksfordzka psychologia spoteczna. Pod red. W. D o m o c h o w s k i e g o, M. A r g y le. Warszawa 1994 s. 197-208.

61 A. Ć wikliński: $O$ rozwój emocjonalno-wolicjonalnych aspektów edukacji. W: Dydaktyka ogólna wyzwania a rzeczywistość. Pod red. K. D e n k a, F. B e reźn i c k i e g o, J. Ś wi r k o - Fi l i p c z u k. Szczecin 2001 s. 151.
} 
cjonalne są kluczowe dla wzajemnych stosunków interpersonalnych i bardzo ważne dla funkcjonowania jednostki. Umiejętności emocjonalne nabywane są stopniowo w procesie uczenia się i każdy człowiek może stawać się coraz bardziej osobą kompetentną emocjonalnie.

Formacja osób świeckich konsekrowanych z pewnością powinna pomagać w kształtowaniu kompetencji emocjonalnych, bowiem jest to bardzo ważna płaszczyzna rozwojowa każdego człowieka. A najdoskonalszym wzorem osiągania dojrzałości emocjonalnej jest sam Jezus, który potrafił świadomie przeżywać i wyrażać bardzo różne stany emocjonalne. Należy jednak zdawać sobie sprawę z tego, że rozwijanie kompetencji emocjonalnych wymaga świadomej pracy nad sobą od każdego formowanego. Niemniej kwestia ta wymaga w pierwszej kolejności dobrego przygotowania wychowawców i formatorów, którzy pełnią bardzo ważną rolę w procesie formacji. Nie ma, niestety, jednej recepty na osiągnięcie sukcesu w rozwoju człowieka, jak nie ma również uniwersalnych metod, skutecznych sposobów w każdym przypadku i reguł, które gwarantują sukces formacyjny. Są natomiast filary, bez których każde działanie wychowawcze, formacyjne może zakończyć się porażką. Takimi ważnymi filarami w kształtowaniu emocjonalnych kompetencji są uwaga, czas oraz otwartość. 